\title{
AGE OF THE AURIFEROUS SLATES OF THE SIERRA NEVADA
}

\author{
BY JAMES PERRIN SMITH
}

(Presented before the Society December 29, 1898)

\section{CONTENTS}

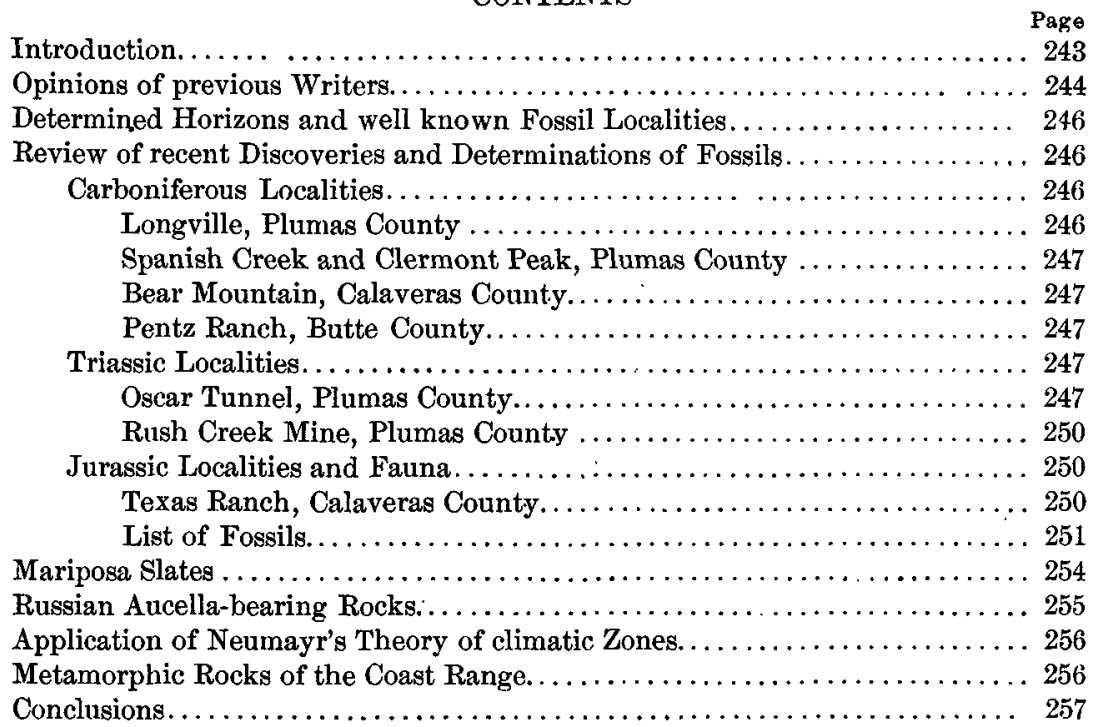

\section{INTRODUCTION.}

During the autumn of 1893 the writer spent five weeks in field work on the Auriferous slates of the Sierra Nevada, chiefly in Plumas, Butte and Calaveras counties, California, in the effort to find some definite horizons that might be identified by fossils. In this he was greatly aided by $\mathrm{Mr}$ James E. Mills, under whose guidance he visited many of the localities mentioned in this paper. To Mr Mills is due in great measure whatever success was achieved by the investigations. 
The Auriferous slates have long been a puzzle to California geologists, and, on account of the scientific as well as economic interest attached to them, much has been written-hardly any two writers agreeing-about their age.

This paper is intended to present the facts known at the present time.

\section{OpINIONS OF PREvious Writers.}

1858. The first geologist to write about the age of the Auriferous slates of the Sierra Nevada was W. P. Blake,* who stated that a great part of the gold-bearing formation would probably prove to be Silurian and Devonian.

1859. Sir R. Murchison also thought that these rocks were Paleozoic, mostly Silurian. $\dagger$ The work of Dr John B. Trask $\ddagger$ in finding Carboniferous fossils in the metamorphic rocks of Shasta county seemed to confirm these opinions, for the McCloud river rocks are almost in the prolongation of the strike of the Auriferous slates of the Sierra Nevada. L. Simonin $\$$ claims to have found trilobites in the slates, but does not give the locality. J. Marcou || says that they were found in Mariposa county, and were preserved in the museum of the University of Santiago, Chile.

1864. The first reference of the Auriferous slates to other than Paleozoic age was made by J. D. Whitney, who said that they consisted largely of Trias and Jura. This was based on the finding of undoubted Triassic and Jurassic fossils in Indian valley, Plumas county, and of rather uncertain Jurassic fossils on the Mariposa estate, Mariposa county.

1865. F. B. Meek afterward published ** descriptions and figures of the Jurassic fossils of the Mariposa slates. Whitney $\dagger$. refers to the finding of Goniatites (Celtites?) lavidorsatus, Gabb (not Hauer), in Tuolumne county between Knight's and Robinson's ferries on Stanislaus river, at the mouth of Mormon creek, and in Eldorado county at Spanish Flat. On this evidence, together with the finding of Upper Trias near Taylorsville, Plumas county, he refers part of the Auriferous slates to the Trias.

1870. W. M. Gabb+‡ published the opinion that all the Jurassic deposits of the Sierra Nevada and their vicinity were probably of Liassic age.

1876. J. F. Whiteaves $\$ \S$ thinks that Aucella erringtoni is the equivalent

* Pacific Railroad Report, 1858, Introduction, p. iv.

† Murchison: "Siluria," third edition, 1859, pp. 455 and 475.

$\ddagger$ Report on the Geology of the Coast Mountains, 1855.

Comptes Rendus, tome L, 1860, p. 391.

|l Bull. Soc. Geol. France, 1883, p. 409.

II Am. Jour. Sci., September, 1864, p. 261.

** Geology of California, rol. i, Appendix B.

† Paleontology of California, vol. i, p. 279.

¥Am. Your. Conch., vol. v, p. 5 .

¿3Geol Survey of Canada, Mesozois Fossils, vol. i, part i, p. 86 . 
of A.piochi, and that the Auriferous slates are possibly Tithonian, a transition from Jura to Cretaceous.

1880. On page 39 of "Auriferous Gravels of the Sierra Nevada of California," J. D. Whitney outlines the Auriferous slates as "all the metamorphic sedimentary rocks of the Sierras," and says that they are of both 'Triassic and Jurassic age, but that none are Cretaceous, for rocks of that age lie unconformably on the metamorphic series. $\mathrm{He}$ thinks also that it is doubtful whether there are any Paleozoic rocks in the series, for there is no proof that the limestones of the Auriferous slates are a continuation of those in Shasta and Butte counties. Professor Whitney also gives a section of the Auriferous slates, in which he divides them into two great divisions: the upper containing the Mariposa slates and diabase-tuff, and the lower containing mica-schists and limestones ${ }^{6}$ which may be equivalent to those at Pentz ranch, Butte county, and therefore Carboniferous.

1883. J. Marcou * says the Mariposa slates are Triassic in age, and that they belong to the Rhetic, or zone of Avicula cortorta; also that Ammonites colfaxi is of Triassic type.

1884. J. F. Whiteaves $\dagger$ says that certain so-called Jurassic rocks (i.e., the Mariposa slates) may be Cretaceous and not Jura. The same he thinks is true of the Jura of the Black hills, and most of the other socalled Jura in the west.

1885. C. A. White $\$$ says that Aucella erringtoni and A. piochi are equivalent; and that part of the Auriferous slates are thus of Knoxville (Neocomian) age. Another part he thinks may be of Paleozoic age. $\mathrm{He}$ concludes that if all the Aucella-bearing rocks are Neocomian there is probably no Jura in California, as all the so-called Jura is probably equivalent.

1886. J. S. Diller $\S$ says that the auriferous slates are part Carboniferous and part Mesozoic.

1888. G. F. Becker $\|$ discusses the relations of the Mariposa slates to the Knoxville, and concludes they are identical, because of the supposed identity of Aucella erringtoni and $A$. piochi, no other supposed Shasta species being found in the Mariposa slates. Doctor White 9 discusses the age of the Aucella-bearing beds of the Coast range, classes them with the Neocomian, and says that the Aucella beds of the Auriferous series-that is, the Mariposa slates-are their equivalents.

* Bull. Soc. Geol. France, 1883, p. 410.

$\dagger$ Geol. Survey Canada, Mesozoic Fossils, vol. i, part iii, pp. 260-261.

† Bull. 15, U. S. Geol. Survey, pp. 24-26.

3 Bull. 33, U. S. Geol. Survey, p. 16.

II Monogrıtph xiii, U. S. Geol. Sturvey, pp. 198-204.

IMonograph xiii, U.S. Geol. Survey, Appendix to chapter v. 
1891. G. F. Becker* concludes that the Mariposa slates are Gault. H. W. Fairbanks $\dagger$ says that the evidence is in favor of the Jurassic age of the Auriferous slates and the limestones associated with them.

1892. James E. Mills $\ddagger$ gives about the same stratigraphy of the Sierra Nevada rocks as that given by Whitney, $\S$ and refers one portion of the series to pre-Mesozoic time; another to Lower Mesozoic, on the evidence of the occurrence of Pentacrinus and Ammonites colfaxi, both supposed to be indicative of Jurassic age, and a third portion he refers to Upper Mesozoic from supposed equivalence with the Mariposa slates.

1893. G. F. Becker $\|$ divides the Auriferous slates series into the Calaveras formation and the Mariposa formation. The Calaveras formation is to include all the Paleozoic deposits of the Sierra Nevada, except the Silurian, described by J. S. Diller, from Plumas county, $\boldsymbol{\Upsilon 1}$ and afterwards named the Grizzly formation.**

The Mariposa formation makes up the upper division of the Auriferous series. None of the supposed Triassic of the Sierra Nevada comes within this sheet, but similar ones at the northern end of those mountains have been named the Cedar t formation.

H. W. Turner + gives several localities for Carboniferous and Mesozoic fossils in the Auriferous slates series, but does not give any exact horizon.

\section{Determined Horizons and weli-known Fossil Localities.}

In presenting the results of the investigations it seemed best to the writer to give in tabular form all the known localities for fossils in the metamorphic series, and then to follow with a discussion of those occurrences about which new information could be added.

\section{Review of Recent Discoveries and Determinations of Fossils.}

\section{CARBONIFEROUS LOCALITIES.}

Longville, Plumas County.-This locality, which is near the town of Longville, was first mentioned by J. S. Diller, §§ who found there Lithostrotion whitneyi, Meek, Lophophyllum proliferum (?) and a Spirifer (?). In a later paper |||| he refers to this locality again, and quotes C. D. Walcott

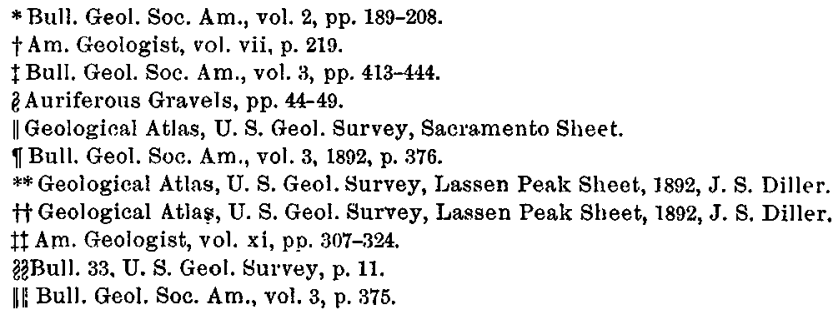


on the probability of this being Lower Carboniferous. The writer visited the place in October, 1893, and collected L. whitneyi, Fusulina cylindrica, Eumetria, Spirifer cameratus (?), Aviculopecten (?), Conocardium (?) and many round crinoid stems. In diabase-tuff just above the limestone was found a Productus, possibly $P$. semireticulatus. This fauna is probably equivalent to that of the upper part of the McCloud river imestone, which lies a thousand feet or more above the Lower Carboniferous siliceous shales of Baird, Shasta county, and thus would in all probability represent the lower part of the Coal Measures.

Spanish Creek and Clermont Peak, Plumas County.-A letter from $\mathrm{Mr} \mathrm{H}$. W. Turner, September 13, 1893, says that Mr T. W. Stanton has collected Fusulina cylindrica and other Carboniferous forms from a locality on Spanish creek one mile east of Spanish ranch; also corals, et cetera, probably Paleozoic, from the limestone on Rock creek, about a mile and a half northwest of summit of Clermont peak. The writer visited these localities, and on Spanish creek found Lithostrotion whitneyi, Favosites, Campophyllum (?) and numerous round crinoid stems. On Rock creek he found a Campophyllum and crinoid stems. There can be no doubt that both localities are of Carboniferous age.

Bear Mountain, Calaveras County.-H. W. Turner* says that the United States Geological Survey has found Fusulina cylindrira, Zaphrentis, and round crinoid stems in the limestone of Bear mountain and in the continuation of this belt northward. In November, 1893, the writer found also a Michelinia in the limestone of a quarry on A. R. Young's place, five miles northeast of Valley springs. James E. Mills also collected a Zaphrentis from a quarry in township 5 north, range 11 east, section 32 , northeast quarter of southeast quarter, on the road between Campo Seco and Mokelumne hill.

Pentz Ranch, Butte County.--J. D. Whitney † assigns these limestones to the Carboniferous, while James E. Mills + refers them to the lower Mesozoic, but without any paleontologic evidence. The writer failed to find any brachiopods, but found a Favosites and Archrocidaris, and numerous very large round crinoid stems which resemble Poteriocrinus.

TRIASSIC LOCALITIES.

Oscar Tunnet, Plumas County.-J. S. Diller $\$$ includes this locality in his Cedar formation, the equivalent of the Hosselkus limestone, Upper Trias, of the Genesee valley. In a letter of August 13,1893, Mr Diller announces the discovery of Ammonites, Pentacrinus and other fossils in

*Am. Geologist, vol. xi, p. 309.

$\uparrow$ Geol. of California, vol, i, p. 210.

$\ddagger$ Bull. Geol. Soc. Am., vol. 3, p. 434.

GGeol. Allas, U. S. Geol. Survey, Lassen Peak Sheet. 


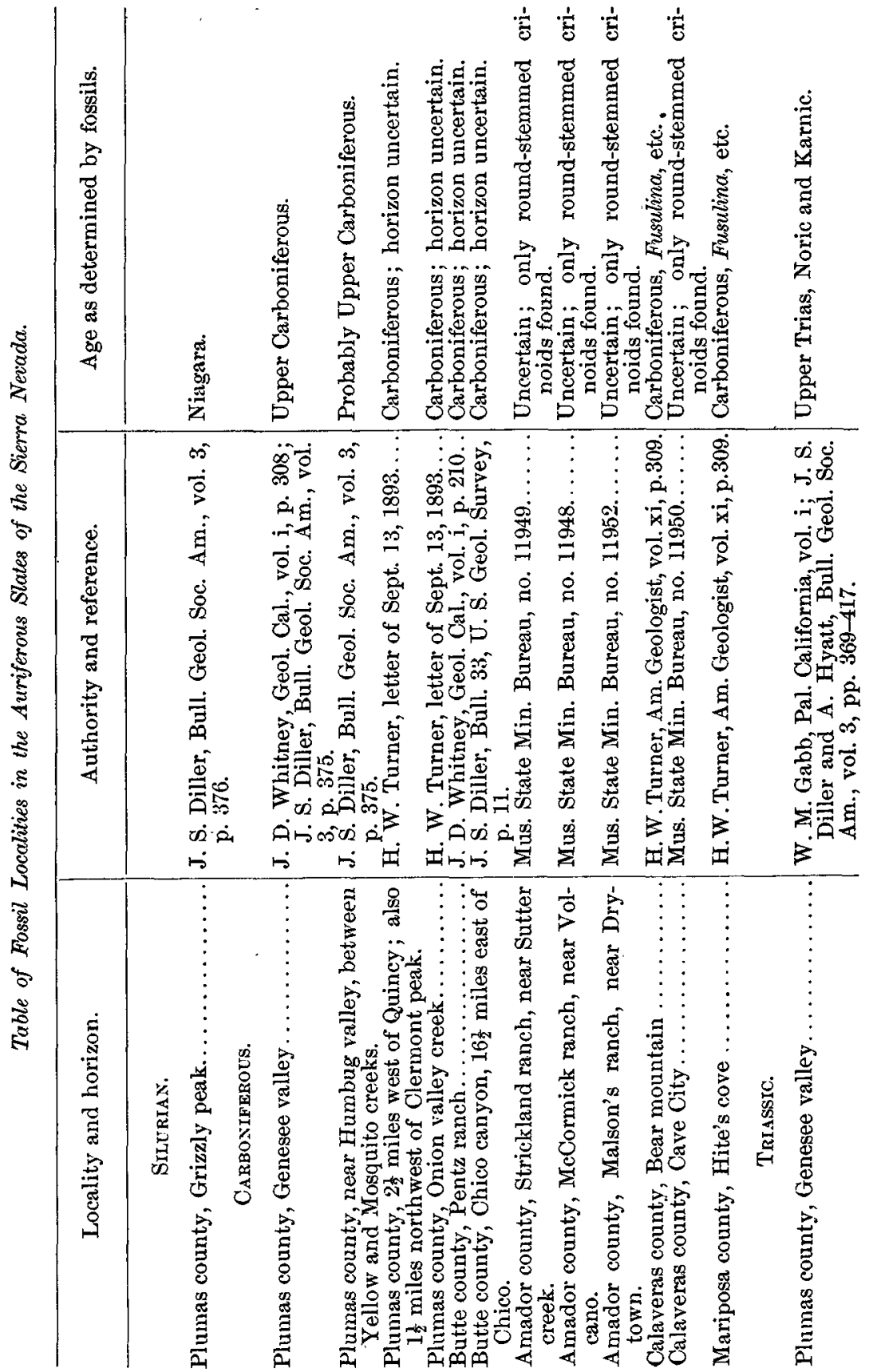


TABLE OF FOSSII, LOCALITIES.

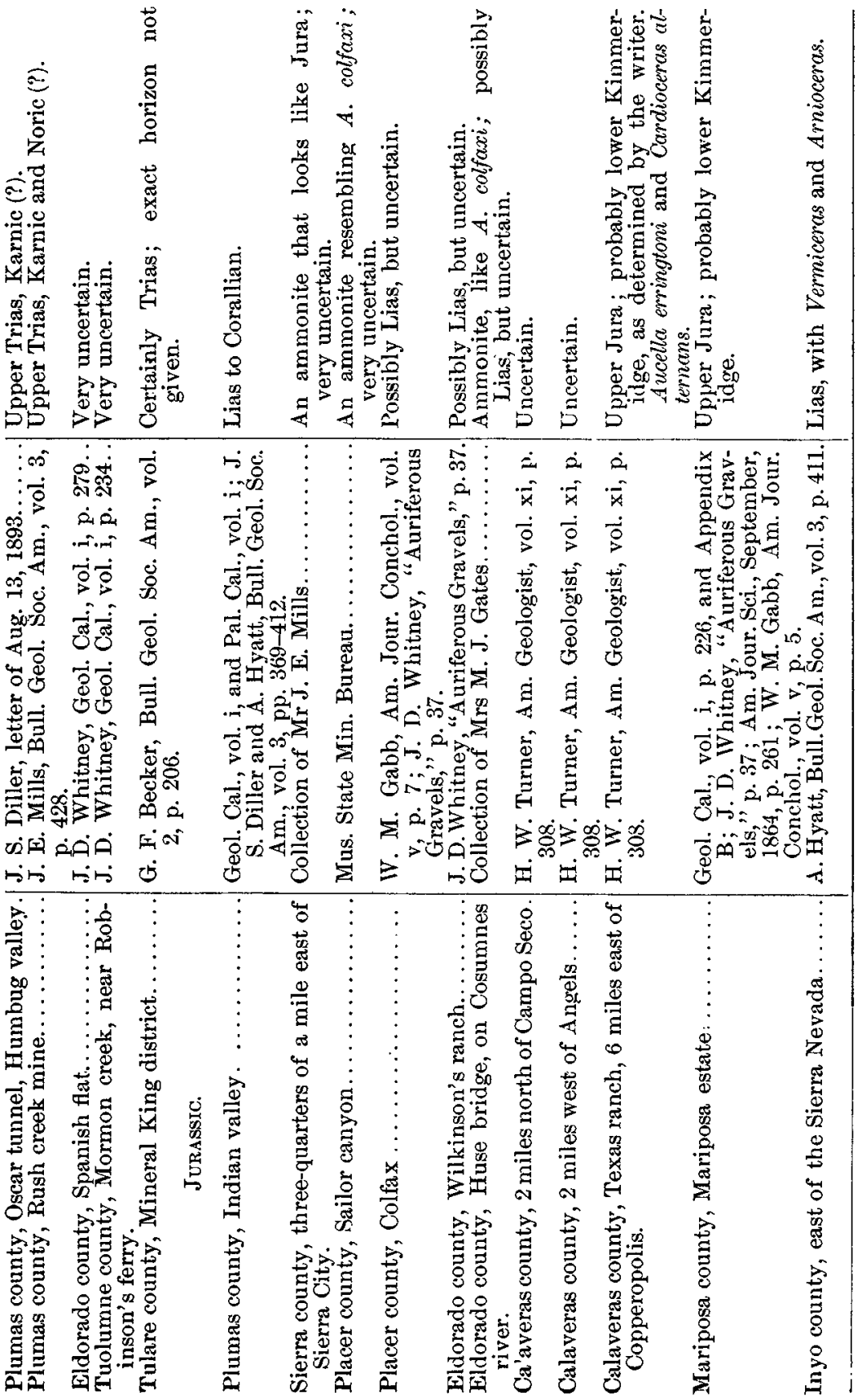


the Trias of this region. The writer visited this locality in October, 1893, and found Pentacrinus, Encrinus(?) Spiriferina and Attractites. The evidence is therefore sufficient to place these rocks in the upper part of the Trias, probably Karnic.

Rush Creek Mine, Plumas County.--J. S. Diller* includes this limestone in his Cedar formation, basing his conclusions on the Triassic fossils he found there.

James E. Mills $\dagger$ published the first notice of the occurrence of Pentacrinus in these beds, and called them Jurassic or later, upon the opinion of Dr Charles Wachsmuth, who thought that this type of crinoids did not antedate the Jurassic. Pentacrinus, however, is well known to occur in the Trias in Europe, and has been found in rocks of that age in three other places in California, associated, as in this case, with undoubted Triassic fossils.

In October, 1893 , the writer visited this locality in company with Mr Mills, and found numerous characteristic Upper Triassic fossils of the horizon of the Hosselkus limestone. At the top of the series was seen diabase-tuff with pebbles of granitoid rock. Below this were several feet of shaly siliceous limestone with pebbles of phthanite and granitoid rock, Pentacrinus, Cidaris, Spiriferina and an undescribed species of Tropites, identical with specimens collected in Shasta county. Below the Pentacrinus limestone are seen dark, very thin bedded shales, which, where not too much altered, showed Attractites and Halobia superba (?), Daonella (?), and Avicula. This fauna is identical with that described by $A$. Hyatt $\ddagger$ from the Genesee valley, and also with that found by H. W. Fairbanks between Squaw creek and Pit river, Shasta county. It is of Karnic age of the Upper Trias, and the stratigraphy agrees with that of Plumas and Shasta counties, where the Halobia slates underlie the Hosselkus limestone.

Below the Halobia slates are about 1,500 feet of siliceous, dark shales and tuffs, very much like the underlying shales of Shasta county, where they are known from fossils to be in part of Triassic age, probably Noric. In the Rush creek region no fossils were found in them. Next to the shales is a large mass of serpentine, but it is not known whether it is conformable or not, or whether it underlies them.

\section{JURASSIC LOCALITIES AND FAUNA.}

Texas Ranch, Calaveras County.-This locality, which is on the ranch of Charles Grossman ("Texas Charlie"), is in the valley of Angels creek,

* Geol. Atlas, U. S. Geol. Survey, Lassen Peak sheet, 1892, top of third column of descriptive text.

† Bull. Geol. Soc. Am., vol. 3, p. 428.

$\ddagger$ Bull. Geol. Soc. Am., vol. 3, pp. 395-412. 
500 yards north of the Sonora stage road. It has been known for several years, but the only published mention of it was made recently by $\mathrm{H}$. W. Turner,* who notes the occurrence of aucellæ and ammonites in the slates. In 1893 James E. Mills sent to the writer some fossils from this locality, including an Aucella, a Pecten, an ammonite and fragments of wood.

In November, 189:3, the writer visited the region and noted that east of Copperopolis is a large thickness of diabase-tuff, interbedded with crystalline limestone, which is best seen about four miles east of Copperopolis. The limestone strikes northwest-southeast, and shows traces of fossils, but they could not be determined. East of the diabase-tuff and limestone is a considerable thickness of serpentine, and still further east is a thickness of several hundred feet of finely laminated slates, interbedded with conglomerates and some serpentine. On the stage road to Sonora about six miles east of Copperopolis and on the east slope of Bear mountain are found a few aucellæ, and in the valley, at the Texas ranch locality previously described, the slates are seen again in places with many fossils-lamellibranchs and cephalopods. The fauna is a very interesting one and characteristic of Upper Jurassic and of either Corallian or lower Kimmeridge age.

List of Fossils. - The following is a systematic list of the fossils found here:

Rhynchonella, sp.

BRACHIOPODA.

One specimen, not in a condition to figure, seems to present the characteristics of Rhynchonella, but is so flattened that no certain determination could be made. It resembles somewhat Rhynchonella myrina, Whitfield. Geology of the Black Hills of Dakota, p. 347, pl. III, figs. 6,7 .

LAMELLIBRANCHIATA.

Amussium (Entolium) aurarium, Meek. Geol. of California, vol. i, p. 478, pl. I, fig. 6.

Lima, sp.

A small Iima, with heavy, radiating ribs, was found, but could not be determined specifically.

Aucella erringtoni, Gabb.

Lima erringtoni, Gabb. Proc. California Acad. Sci., November, 1864, p. 173.

Aucella erringtoni, Gabb, F. B. Meek. Geol. of California, vol. i, p. 479, pl. I, figs. 1, 2, 3, 5, 7 .

*Am. Geologist, May, 1893, p. 308.

XXXV-Bur.,. Gmor. Soc, Am., Vor. 5, 1893. 
Aucella concentrica, Fischer, Dr C. A. White. Monograph XIII, U. S. Geol. Survey, p. 230, pl. IV, figs. 6-10.

This species, whose affinities were first recognized by Meek, occurs in great numbers in the slates at Texas ranch in all stages of compression and distortion, so that specimens may be obtained showing all the variations figured by Meek, and many others also.

C. A. White* unites A. erringtoni, Gabb, with Aucella piochi, Gabb, of the Knoxville group, Neocomian, and with A. pallasi, Keyserling, and A. mosquensis, von Buch of the Upper Jura of Russia, and A. ercassicollis, Keyserling of the Lower Cretaceous, Neocomian, of Russia. But it has been shown by Lahusent that the Russian species are not all the same, but are well characterized, and are found in very different horizons and with different faunas, and thus thenselves become in a measure indexfossils. Lahusen† has represented this in a table, dividing the Russian Upper Jurs and Lower Cretaceous into zones on the basis of the occurrence of the various species of Aucella. Thus Aucella pallasi, Keyserling, is shown to be confined to the Upper Jura and to range from the upper Oxford to the lower Portland; A. mosquensis, von Buch, ranges from the middle Portland into the lower portion of the upper Portland, while A. crassicollis, Keyserling, is confined to the Lower Cretaceous, Neocomian, and is very similar to if not identical with $A$. piochi, Gabb, of the Knoxville. Aucella concentrica, Fischer, is not recognized by Lahusen, because Fischer de Waldheim described under that specific name several different species from different horizons ranging from Oxford to Neocomian. It therefore becomes extremely improbable that all the American species of Aucella are identical with each other, since they have been based on this hybrid species. Meek, in his description of $A$. erringtoni, Gabb, $\S$ notes the similarity to $A$. pallasi, Keyserling, and says they are very possibly identical. Lahusen, in his monograph, $\|$ also notes the resemblance between left valves of $A$.erringtoni and $A$. pallasi, and on page 33 of the same work he compared the right valves of $A$. erringtoni and $A$. bronni, Rouiller, the only difference between them being that on the California species the radial lines are very distinct only on the anterior part of the shell. But in the collection from Texas ranch are numerous specimens that have the radial lines just as strong on the posterior as on the anterior part of the shell, and some even stronger. It thus becomes probable that $A$. erringtoni, Gabb, represents in reality the two species, $A$. pallasi, Keyserling, and A. bronni, Rouiller, which, because of the state of preservation, we are not now able to distinguish from each other.

* Monograph xiii, U. S. Geol. Survey, p. 230.

† Mém. Com. Géol. (Russia), 1888, vol. viii, no, 1, "Ueber Russische Aucellen."

† Op. cit., p. 2 i.

¿Geol. of California, vol, j, p. 480 .

II Mien. Coln. Giol., vol, viii, no. I, p. 3.T. 


\section{CEPHALOPODA.}

Belemnites pacificus, Gabb. Proc. Cal. Acad. Sci., Nov., 1864, p. 173.

This species has never been figured from California, but one from Alaska supposed to be identical with it has been described by C. A. White* as associated with Aucella. In the slates at Texas ranch a few specimens were found, but too imperfect to be satisfactorily identified.

Cardiocerus alternans, von Buch.

Ammonites alternans, I. von Buch, Gesammelte Werke, vol. iv, p. 454, pl. 18, fig. 4.

Ammonites alternans, Quenstedt. Ammoniten des Schwäbischen Jura, p. 824, pl. 91, figs. 1-25.

This species is a very variable one, and probably not all the varie. ties united by Quenstedt are the same; still this group of Cardioceras is well marked and easily distinguished from that of $C$. cordatum, Sowerby, and $C$. cordiforme, Meek and Hayden. This species differs from $C$. cordiforme, Meek and Hayden, $\dagger$ in having the sides less arched and the involution less; also on C. cordiforme the ribs are more numerous and usually each alternate rib forks at the umbilicus and swings with a gentle curve forward, nowhere showing a tendency to produce knots. In C. alternans the ribs fork with great irregularity, sometimes each alternate one and sometimes the third or fourth. They fork about half way to the outside or ventral portion of the shell, forming usually a small knot at the fork, and often forming a second one where the ribs make their sickle-shaped bend forward on the external side.

The very high, sharp, strongly serrated keel is characteristic of this species.

The specimens are all distorted from the crushing of the slates, and thus are elliptical instead of spiral, but they show the same amount of involution as that given on the figures of Quenstedt. The umbilicus is much wider and less deep than that of C. cordiforme. Meek and Hayden, or C. cordatum, Sowerby.

The body chamber is about one coil in length.

A closely related species has been described by Pavlow $\$$ under the name Cardioceras volgx, Pavlow, of the zone of Aspidoceras acanthicum, lower Kimmeridge, but that species is much more involute than the California specimens, while the fineness of the costæ is about the same.

Cardioceras subtilicostatum, Pavlow, $\S$ is still more closely related to our species, but is also more involute. It may be identical with a variety of

\footnotetext{
* Bull, 4, U. S. Geol. Survey, p. 14, pl. vi, tigs. 13, 14.

$\uparrow$ Pal. Upper Missonri, p. 122, pI. v, fig. 2 .

f Mem. Com. (ricol. (Russia), vol. ii, no. 3, p. sti, pl. viii, fig. 5 .

3 Op. cit., p. 86.
} 
C. alternans described by P. de Loriol.* Thus the Russian and the Californian specimens may represent extremes of the same species. If this Californian species should not be identical with C.alternans, I would suggest the name Cardioceras whitneyi for it.

Cardioceras alternans is confined to the upper Oxford in Germany, but in Switzerland and in Russia ranges up into lower Kimmeridge-that is, into the lower part of the zone of Aucella bronni. Thus the beds containing this fossil must be of Upper Jurassic age and between the upper Oxford and the middle Kimmeridge. The accompanying Aucellæx being closely related to both $A$. bronni and $A$. pallasi makes it probable that they belong to the higher part of the series, that is, to the lower Kimmeridge.

Perisphinctes (?).

One fragment in the slates is entirely different from the common Cardioceras, and seems to have the characteristics of Perisphinctes, but it is very doubtful.

The fauna of the slates of Texas ranch, Calaveras county, is plainly the same as that of the Mariposa slates, and any evidence of the age of the one applies to the other also.

\section{Mariposa Slates.}

In the first part of this paper the opinions of various writers have been given as to the age of the Mariposa slates, which, upon supposed paleontologic evidence, have been assigned to various periods, ranging from the Trias to the Gault; but from what has been said of the slates at Texas ranch it is seen that the Aucella beds of Mariposa are of the age originally assigned to them by Gabb, $\uparrow$ although Meek recognized their position more accurately by comparing the Aucella $\ddagger$ to a European species of known position.

There can no longer be any doubt that the Mariposa beds belong to the lower part of the Upper Jura, and are thus probably the youngest Jurassic deposits known in North America, with the possible exception of the Corallian described from mount Jura, Plumas county, by A. Hyatt. §

Professor Hyatt || shows that the Jura of the Black hills and adjoining regions belongs to the Callovian or lower Oxford, but that in that time

* Abhandl. Schweizer Paläont. Gesell., vol. iii, "Monographie Zone A. tenvilobatus de Baden," p. 20, pl. i, figs. 17 and 18.

†Proc. California Acad. Sci., vol, iii, p. 172

\$ Geol. of California, vol. i, p. 470).

?. Bull. Geol. Soc. Am., vol, 3, p. 40s,

IIOp. cit., p. 409. 
there was probably no direct connection between the Californian Upper Jurassic deposits and those of the interior.

M. Neumayr* has shown the possibility of some of the so-called Lower Cretaceous of British Columbia being Jurassic, and if so, it would be very much higher, that is, Portland.

\section{Russian Aucellla-bearing Rocks.}

Since the confusion as to the age of the Mariposa slates originated from a mistake as to the age of the Aucella-bearing beds of Russia, a few words about these strata may not be out of place.

The earlier geologists united the younger Mesozoic deposits of Russia under the name "Wolga Stage," which most of them thought to be Upper Jurassic, although some of them, among whom Eichwald was chief, recognizing Cretaceous affinities in some of the fossils, declared the Wolga stage to be Cretaceous.

Professor Whiteaves $t$ has gone still further and declared all the Aucella-bearing rocks of Europe and America to be Cretaceous. This view has been emphatically rejected by Neumayr $\ddagger$ and Doctor White $; \S$ but there never was any controversy as to the Jurassic age of the zones of Cardioceras cordatum and of C. alternans, which were always recognized as belonging to the Kelloway-Oxford and Oxford-Kimmeridge respectively. In these zones are found several species of Aucella.

The later works $\|$ of Pavlow, Nikitin, Lahusen, Michalski and others have shown that the Wolga stage is not a unit, but may be divided into two distinct horizons-the lower Wolga stage, which corresponds to the lower and middle Portland, and the upper Wolga stage, which corresponds at the base to upper Portland, and at the top to Neocomian. The correlation of these deposits has been materially advanced by the comparison of the Speeton clays of England with the upper Wolga stage of Russia, by Pavlow 9 and Lamplugh, in which numerous species are cited as being characteristic of the same horizons in the two countries; among these may be mentioned Aucella pallasi, Keyserling, which is said by Nikitin** to be the same as Avicula vellicata, Blake, of the lower Portland or Bolonian stage.

Doctor White f† admits that Aucella may have been a Jurassic genus

* Denk. K. Akad. Wiss., Wien, 1885, p. 96.

† Geol. Surv. Canada, 1884, Mesozoie Fossils, vol, i, part i, pp. 258-2til.

† Geograph. Verbreitung Jura, p. 96.

Am. Jour. Sci., vol. xxix, 1885, p. 228.

\| For a résumé of the literature of this subject, see A. Pavlow, Bull. Soc. Impér. Nal. Moseow. 1889, no. 1, "Jurassique Supérieur et Crétace Inforieur de la Russie et de la Angleterre."

T Bull. Soc. Imper. Nat. Moscow, 1891, nos. 3 and 4.

*** Bull. Soc. Impér. Nat. Moscow, 1889, no. 1, p. 38.

tf Monograph xiii, U. S. Geol. Survey, p. 224. 
in Russia, and thinks that the time consumed in migrating from Russia to America might explain its occurrence in Cretaceous rocks in America.

But now it becomes just as possible that they migrated the other way, since we have Aucella in California in rocks of probably as great age as any in Russia. In fact, it becomes more probabie when we consider the fact that in a country so near to Russia as England Aucella did not appear until lower Portland time.

\section{Application of Neumayr's Theory of Climatic Zones.}

M. Neumayr refers the Jura of California * and Nevada to the middle European type, while admitting that there were some Arctic elements, such as Aucella. The Jura of the Black Hills $\dagger$ he refers to the boreal type, on account of the occurrence of Cardioceras.

In a later work $\ddagger$ Neumayr says that the California Jura shows a commingling of boreal with temperate zone types, because the two oceans joined in this region, and that it was separated from the Black hills region by a strip of land.

Professor Hyatt $\S$ has shown that the Upper Jura of Plumas county is of central European type, and that it was separated from that of the Black hills district. We have, then, in Calaveras and Mariposa counties a boreal type of Jura about 160 miles south of a temperate zone type. Something similar was recently observed by $\mathrm{Dr} A$. Tornquist $\|$ in the Jura of East Africa, where he found that the distribution of Jurassic forms could not be explained upon the supposition of parallel climatic zones, but rather upon the theory of separate provinces, that is, of more or less separated sea-basins in which, individually, of course, climate will show its effects.

The Jura of Mariposa is boreal if that of the Black hills region is, for it contains even more Arctic elements.

\section{Metamorphic Rocks of the Coast Range.}

J. D. Whitney 9 considered the metamorphic series of the Coast range to be of Cretaceous age from the supposed continuity of unaltered Cretaceous with the jaspers.

Doctor Becker ** followed Professor Whitney for the same reasons.

* Ueber Klimatische Zonen während der Jura und Kreide Zeit, Denks. K. Akad. Wiss., Wien, 1883, p. 301 .

tOp. eit.. p. 302 .

f " Die Geographische Verbreitıng der Juraformation," Denk. K. Akad. Wiss., Wien, 1885, p. 124-5.

?. Buil. Geol. Soc. Am., vol. 3, p. 410.

|| Jahrb. Hamburg. Wiss. Anst. X 2, "Oxford fauna von Mtari," p. 24.

I) Geol. of California, vol. i, and "Auriferous Gravels."

** Monograph XIII, U.. S. Geol. Survey. 
It has been shown by J. S. Diller* and T. W. Stanton that there is no break between the Shasta and the Chico groups; therefore any metamorphism that affected the Knoxville ought to have affected the Chico also; but this is nowhere the case. Mr Diller has further shown that the uplift and metamorphism was pre-Cretaceous in the Klamath mountains and in the northern Sierra Nerada.

H. W. Turner $†$ assumes that the metamorphic series of mount Diablo pass over into the unaltered Knoxville, but without any convineing proof, as he afterwards admits.+

H. W. Fairbanks $\S$ says that he has traced the phthanites of the Klamath mountains into those of the Coast range, and throughout both these mountain chains has found the Knoxville beds, when present, resting everywhere unconformably on this metamorphic core of pre-Cretaceous rocks. All these writers agreed that if Aucella could be found in the metamorphic series, its Cretaceous age would be settled.

But from what has been said as to the age of Aucella-bearing beds in Europe it becomes plain that such is not the case. In 1892 the writer found in the metamorphic phthanite series of Alum Rock canyon near San José several aucellæ of the type A. mosquensis, Buch, as figured by Iahusen; || also in Stevens creek canyon, about 13 miles west of Mountain View, Santa Clara county, he found in very silicious, black metamorphic shale aucellix that agree with Aucella trigonoides, Lahusen.

Now these two species of Aucella in Russia are confined to the middle and upper Portland, of the Upper Jura. It is therefore probable that at least a part of the Coast range metamorphics are of Upper Jurassic age.

A. C. Iawson accepts the pre-Cretaceous age of the Coast range metamorphics, but thinks the uplift was pre-Jurassic and that the erosion took place during the Jura.

From what has been said it is seen that the uplift and metamorphism was of late Jurassic age in at least a portion of the Coast range.

\section{CONCLUSTONS.}

The Auriferous slates are known to consist of Silurian, Carboniferous, Triassic and Jurassic strata.

The Mariposa slates are of Upper Jurassic, probably lower Kimmeridge. age.

\footnotetext{
* Bull. Geol. Soc. Am., vol. 4, pp. 205-224 and pp. 245-256.

† Bull. Geol. Soc. Am., vol. 2, p. 394.

† Ain. Geologist, vol. xi, 1893, p. 314.

Am. Geologist, Mareh, 1892, and February, 1893.

| Mim. Com. Giol. Russie, vol. viii, no. i, p. 36, pl. 11, figs. 21-24.

I Jour. Geology, vol, i, p. is:3, "The Cordilleran Mesozoic Revolution.
} 
The uplift and metamorphism of the Sierra Nevada and of the Coast range occurred in late Jurassic time, before the deposition of the Cretaceous.

Neumayr's theory of climatic zones cannot be applied with exactness to the Jura of California, which can be understood only by the study of the geographic provinces of that time.

Stanford University, Califorita. 